\title{
Evaluation of Gene Therapy as an Intervention Strategy to Treat Brain Injury from Stroke
}

\author{
Amanda J. Craig* and Gary D. Housley \\ Translational Neuroscience Facility \& Department of Physiology, School of Medical Sciences, University of New South Wales, \\ Sydney, NSW, Australia
}

Stroke is a leading cause of death and disability, with a lack of treatments available to prevent cell death, regenerate damaged cells and pathways, or promote neurogenesis. The extended period of hours to weeks over which tissue damage continues to occur makes this disorder a candidate for gene therapy. This review highlights the development of gene therapy in the area of stroke, with the evolution of viral administration, in experimental stroke models, from pre-injury to clinically relevant timeframes of hours to days post-stroke. The putative therapeutic proteins being examined include antiapoptotic, pro-survival, anti-inflammatory, and guidance proteins, targeting multiple pathways within the complex pathology, with promising results. The balance of findings

OPEN ACCESS

Edited by:

George Smith, Lewis Katz School of Medicine at

Temple University, USA

Reviewed by:

Muzamil Ahmad,

Indian Institute of Integrative

Medicine, India

Nicole Déglon,

Lausanne University Hospital,

Switzerland

Stefan Momma,

University Hospital Frankfurt,

Germany

*Correspondence:

Amanda J. Craig

a.craig@unsw.edu.au

Received: 31 January 2016 Accepted: 06 May 2016

Published: 24 May 2016

Citation:

Craig AJ and Housley GD (2016) Evaluation of Gene Therapy as an Intervention Strategy to Treat Brain

Injury from Stroke.

Front. Mol. Neurosci. 9:34.

doi: 10.3389/fnmol.2016.00034 from animal models suggests that gene therapy provides a viable translational platform for treatment of ischemic brain injury arising from stroke.

Keywords: ischemia, viral vector, protein expression, AAV, adeno, herpes simplex virus, lentivirus

\section{STOKE: PREVALENCE AND TREATMENT OPTIONS}

This review considers the opportunity that gene therapy targeting neuroprotective protein expression in the brain may lend to development of novel treatments for stroke. Stroke is a leading cause of death throughout the world, and in Australia, stroke is the leading cause of severe disability; one in five people die within 1 month of their first infarct and one in three die within a year. About $88 \%$ of stroke survivors live at home and most have a disability (Banks et al., 2010; Thrift et al., 2014; Mozaffarian et al., 2015). These statistics reflect the need to develop therapeutics for stroke, whether being an ischemic event, or a hemorrhagic stroke, as there are currently limited clinical treatment options, rehabilitation often frustrates expectation, and the aging population will further exacerbate the health burden from stroke-induced brain injury.

The current treatments for acute ischemic strokes [accounting for $\sim 87 \%$ of strokes (Mozaffarian et al., 2015)] are the intravenous administration of recombinant tissue plasminogen activator (rtPA) to enzymatically digest the thrombi, endovascular therapy to mechanically remove the large proximal clots, or a combination of both treatment regimes, with the aim to restore blood flow to the hypoperfused area. However, the proportion of stroke patients that satisfy the criteria to undergo treatment is low. Approximately $94 \%$ of patients are ineligible for treatment with rtPA (de Los Rios la Rosa et al., 2012; Madsen et al., 2015), due to diminishing benefit and increased risk when administrating rtPA more than $4.5 \mathrm{~h}$ after the ischemic event, in addition to exclusion criteria which includes those patients $>80$ years, taking anticoagulants, with a history of previous strokes in the last 3 months, those with severe or mild strokes, or lacking a penumbral region (de Los Rios la Rosa et al., 2012; Emberson et al., 2014; Saver et al., 2015). Moreover, the effectiveness 
of rtPA is limited; only $\sim 10 \%$ of patients have a better outcome with treatment, with the site and nature of the occlusion appearing to be a factor in efficacy (Paciaroni et al., 2012; Emberson et al., 2014). Hence this approach addresses $<1 \%$ of stroke incidences. There are conflicting reports of clinical outcomes following endovascular therapy, with trials indicating mechanical thrombectomy provides benefit when not coupled with rtPA, the lack of benefit of endovascular therapy with tPA, or that endovascular therapy improves patient outcomes when undertaken following tPA treatment (Broderick et al., 2013; Paciaroni et al., 2015; Saver et al., 2015). In addition to the low eligibility rate to receive treatment following acute ischemic stroke, reperfusion may result in ischemia-reperfusion injury or subsequent hemorrhage (Paciaroni et al., 2012; Emberson et al., 2014).

To date, there are no therapeutic interventions available to inhibit neuronal cell death, or to facilitate regeneration or neurogenesis following a neuronal injury. Research into the cellular and molecular events following an ischemic event in the brain provide a key resource for evaluation of putative therapeutics (Dirnagl et al., 1999; Moskowitz et al., 2010). Of particular interest is a range of endogenous proteins whose expression is up-regulated by stroke-induced brain ischemia, where manipulation of expression may contribute to neuroprotection, neuroregeneration, or neurogenesis. Clinically, it is essential that the manipulation of the expression profile of these proteins is matched to the therapeutic time window following stroke; for example, targeting necrosis, which occurs in the minutes following neuronal injury, may be practically unachievable, whereas manipulation of proteins that have antiapoptotic or anti-inflammatory properties presents a far more realistic timeframe of therapy-delivery in the hours or days following a stroke (Figure 1).

\section{CONSIDERATIONS AROUND GENE THERAPY PLATFORMS}

When undertaking gene therapy, in addition to the success of the treatment being dependent upon the gene target, consideration of the time of delivery in relation to the stroke onset, site of delivery, cell transduction, and onset and duration of gene expression are also critical considerations.

\section{Protein Synthesis}

An advantage of gene delivery as a tool for administration of a therapeutic intervention in a disorder with on-going and delayed cell death is the persistence of synthesis of the therapeutic protein over a prolonged period of time (Hallek and Wendtner, 1996); thereby diminishing the need for repeated

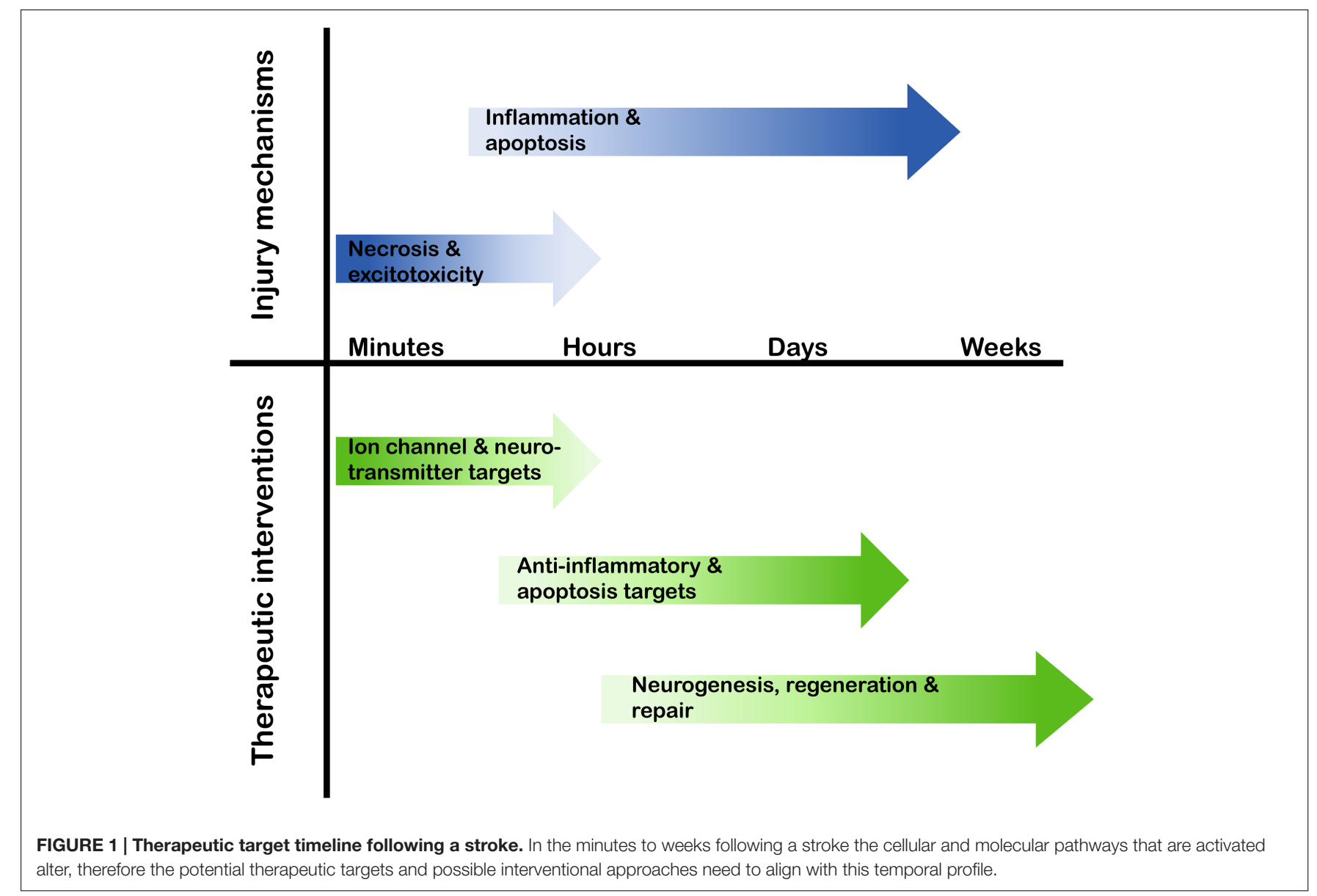


and/or frequent pharmaceutical interventions. In the context of this review, the long-term expression of therapeutic proteins has been demonstrated in rodent models of stroke (Table 1), with proteins evident at 7 weeks following ischemia, with an administration time-point of 3-5 weeks prior to injury, totaling 12 weeks of protein expression (Andsberg et al., 2002; Arvidsson et al., 2003).

Conversely, the reliance of host-mediated protein synthesis of the viral-encoded sequences, following an ischemic event, may be compromised, and, therefore, result in diminished putative therapeutic efficacy, due to the inherent reduction in protein synthesis associated with the brain injury (Kleihues and Hossmann, 1971). Specific to gene delivery, Lawrence et al. (1997) demonstrated herpes simplex virus (HSV)-mediated expression increased at $12 \mathrm{~h}$ following ischemia in ischemic tissue; however non-ischemic tissue had increased expression, to a greater extent, as early as $8 \mathrm{~h}$ post-ischemia. These data not only highlight a delay in peak protein expression, but also a reduction in the extent of expression with the ischemic brain injury (Lawrence et al., 1997).

\section{Delivery Site}

Down-regulation of protein synthesis can be overcome, in part, by viral delivery into a non-affected region of the brain, or to the peri-infarct area, as opposed to the ischemic area (Zhao et al., 2003; Matlik et al., 2014). This approach not only overcomes potential synthesis suppression, but delivery to striatal periinfarct regions of the brain, post-ischemia, has shown to be an effective means of viral distribution, with viral particles hypothesized to travel toward white matter tracts during the period of edema (Matlik et al., 2014). There is also evidence of virally derived proteins in brain regions remote of the initial viral delivery site (Hermann et al., 2001b). Alternatively, viral delivery into sites remote of the brain, such as a stroke-affected limb may promote corticospinal axonal sprouting in the spinal cord from the less affected hemisphere driven by the viral expression of neurotrophin-3 (Duricki et al., 2016). This could present as an alternative approach to the problem of inhibition of axonal re-growth in areas with astrocytic scarring. In contrast, studies have also shown increased striatal neuronal loss following postischemia anterograde delivery of GDNF. Whether this result is due to the delivery mode, the protein being expressed, the relative time of expression, or a combination of all of these, as well as additional factors is yet to be determined (Arvidsson et al., 2003).

An alternative approach to overcome the time-delay of protein expression is to express the viral-derived proteins in stem cells, which are then transplanted by intracerebroventricular injection (Watanabe et al., 2004; Chen et al., 2016). This method has resulted in reduced infarct volume and increased behavioral outcomes and may be a viable adjunct to gene delivery, with clinical trials of stem cell therapy in stroke patients already well established (Jeong et al., 2014).

\section{Viral Vectors}

The design of the viral vector is an important component in gene delivery, ensuring that the virus is not pathogenic or induces neurotoxicity, targeted cell-specific delivery can be facilitated or alternatively the vector can be developed for broad transduction, and gene expression duration can be appropriately modulated. The desired expression profile of the protein should be considered in terms of expression instigation, duration, and efficacy. The four most commonly used viral vectors are HSV type-1 (Bloom et al., 1995; Carpenter and Stevens, 1996), adenovirus (Ad; Akli et al., 1993), recombinant adeno-associated virus (rAAV; Hallek and Wendtner, 1996), and lentivirus (Naldini et al., 1996). Each have their own innate attributes and deficiencies, which must be considered in relation to the size of the gene sequence to be inserted, the target cell population, and the protein expression profile. In addition to the innate variations between viral vector system, viral serotypes will also affect the target cell specificity and protein expression (Davidson et al., 2000; von Jonquieres et al., 2013, 2016). As noted below, HSV vector-mediated expression has been reported with a few hours (Hoehn et al., 2003), whereas other commonly used viral vectors exhibit expression profiles that take days or weeks to establish (Mason et al., 2010). Further alterations in the expression profile of the protein of interest can be driven with capsid modifications, as well as the promoter used to drive gene expression, which can bias glial versus neuronal expression, and the potential to incorporate gene cassette control elements (von Jonquieres et al., 2013, 2016). The broad consideration of technical development of gene therapy platforms for clinical applications, including non-viral modalities, and use of gene regulatory strategies such as shRNA are outside of the scope of this review, which is a perspective on the opportunity and exemplar prospective gene targets.

\section{THERAPEUTIC PROTEIN CANDIDATES FOR STROKE TREATMENTS}

\section{Bcl-2 Family}

In terms of a gene-delivered therapy following stroke, the anti-apoptotic proteins within the B-cell lymphoma-2 (Bcl-2) family, including Bcl-2 itself, Bcl-extra long (Bcl-XL), and Bcl-2-like 2 (Bcl-2l2 or Bcl-w), are an obvious therapeutic choice due to their intrinsic role in modulating apoptosis and neurogenesis (Czabotar et al., 2014). Evidence of the neuroprotective capabilities of $\mathrm{Bcl}-2$ has been demonstrated in a variety of injury models, with roles including modulation of intracellular $\mathrm{Ca}^{2+}$ concentration (Zhong et al., 1993; Murphy and Fiskum, 1999), reducing reactive oxygen species (Kane et al., 1993), and inhibiting the translocation of apoptosis-inducing factor (Zhao et al., 2004), all of which are prevalent following stroke. Furthermore, transgenic mice experiments have shown that over-expression of $\mathrm{Bcl}-2$ provides neuroprotection following ischemia (Kitagawa et al., 1998). In addition, the over-expression of $\mathrm{Bcl}-2$ induces neurogenesis following ischemic injury (Lei et al., 2012).

The therapeutic effectiveness of Bcl-2 anti-apoptotic proteins, expressed from viral vectors including HSV (Linnik et al., 1995; Lawrence et al., 1997; Yenari et al., 2001), Ad (Kilic et al., 2002), rAAV (Sun et al., 2003), and lentivirus (Wong et al., 2005) has been demonstrated in middle cerebral artery occlusion (MCAO) and bilateral common carotid artery (CCA) occlusion models of 
stroke in rodents, as well as a model of excitotoxicity (Table 1). The administration of the viral vector ranged from 3 weeks pre-ischemic insult to $4 \mathrm{~h}$ post-ischemia, which provide proofof-principle data, but are sub-optimal for clinical translation. The most promising studies utilized administration of a HSV-Bcl-2 construct at 30 and 90 min following MCAO, with significant neuroprotection achieved (Lawrence et al., 1997; Yenari et al., 2001). Disappointingly, there was a lack of neuroprotection

TABLE 1 | Viral gene delivery in animal models of stroke.

\begin{tabular}{|c|c|c|c|c|c|}
\hline Protein & Viral vector & $\begin{array}{l}\text { Administration } \\
\text { (pre-/post-injury) }\end{array}$ & Stroke model & Neuroprotective & Reference \\
\hline Bcl-XL & Ad & 7 days pre- & Mouse; 30 min or 2 h MCAO & Yes & Kilic et al., 2002 \\
\hline $\mathrm{Bcl}-2$ & $\begin{array}{l}\text { Lentivirus } \\
\text { HSV } \\
\text { HSV } \\
\text { HSV } \\
\text { HSV }\end{array}$ & $\begin{array}{l}3 \text { weeks pre- } \\
24 \mathrm{~h} \text { pre- } \\
30 \text { mins post- } \\
1.5 \text { h post- } \\
4 \mathrm{~h} \text { post- }\end{array}$ & $\begin{array}{l}\text { Rat; NMDA in hippocampus } \\
\text { Rat; permanent MCAO } \\
\text { Rat; } 1 \text { h MCAO } \\
\text { Rat; } 1 \text { h MCAO } \\
\text { Rat; } 1 \text { h MCAO }\end{array}$ & $\begin{array}{l}\text { Yes } \\
\text { Yes } \\
\text { Yes } \\
\text { Yes } \\
\text { No }\end{array}$ & $\begin{array}{l}\text { Wong et al., } 2005 \\
\text { Linnik et al., } 1995 \\
\text { Lawrence et al., } 1997 \\
\text { Yenari et al., } 2001 \\
\text { Lawrence et al., } 1997\end{array}$ \\
\hline Bcl-w & rAAV & 3 weeks pre- & Rat; 1.5 h MCAO & Yes & Sun et al., 2003 \\
\hline BDNF & $\begin{array}{l}\text { rAAV } \\
\text { rAAV }\end{array}$ & $\begin{array}{l}4-5 \text { weeks pre- } \\
14 \text { days pre- }\end{array}$ & $\begin{array}{l}\text { Rat; } 30 \text { min MCAO } \\
\text { Rat; various MCAO models }\end{array}$ & $\begin{array}{l}\text { Yes } \\
\text { Yes }\end{array}$ & $\begin{array}{l}\text { Andsberg et al., } 2002 \\
\text { Zhang et al., } 2011\end{array}$ \\
\hline CDNF & rAAV & 2 days post- & $\begin{array}{l}\text { Rat; } 1 \mathrm{~h} \text { bilateral CCA and right } \\
\text { MCAO }\end{array}$ & No & Matlik et al., 2014 \\
\hline CNTF & Ad & 7 days pre- & Mouse; 30 min MCAO & Yes & Hermann et al., 2001b \\
\hline GDNF & $\begin{array}{l}\text { Lentivirus } \\
\text { Ad } \\
\text { HSV } \\
\text { HSV }\end{array}$ & $\begin{array}{l}3 \text { weeks pre- } \\
7 \text { days pre- } \\
4 \text { days pre- and } \\
3 \text { days post- }\end{array}$ & $\begin{array}{l}\text { Rat NMDA to hippocampus } \\
\text { Mouse; } 30 \text { min MCAO } \\
\text { Rat; } 1 \text { h MCAO } \\
\text { Rat; } 1 \text { h MCAO }\end{array}$ & $\begin{array}{l}\text { Yes } \\
\text { Yes } \\
\text { Yes } \\
\text { No, but behavioral } \\
\text { improvement }\end{array}$ & $\begin{array}{l}\text { Wong et al., } 2005 \\
\text { Hermann et al., } 2001 \text { a,b } \\
\text { Harvey et al., } 2003 \\
\text { Harvey et al., } 2003\end{array}$ \\
\hline & Ad & During and & Rat; 1.5 h MCAO & Yes & Zhang et al., 2002 \\
\hline & Ad & $1 \mathrm{~h}$ post- & Rat; 1.5 h MCAO & No & Zhang et al., 2002 \\
\hline & rAAV & During & $\begin{array}{l}\text { Rat; } 1.5 \mathrm{~h} \text { bilateral CCA and } \\
\text { right MCAO }\end{array}$ & Yes & Tsai et al., 2000, 2006 \\
\hline HB-EGF & rAAV & 6-7 days post- & Rat; 80 min MCAO & $\begin{array}{l}\text { No, but functional } \\
\text { recovery with } \\
\text { neurogenesis and } \\
\text { angiogenesis }\end{array}$ & Sugiura et al., 2005 \\
\hline NGF & rAAV & 4-5 weeks pre- & Rat; 30 min MCAO & Yes & Andsberg et al., 2002 \\
\hline NT3 & rAAV & 24 h post- & Rat; endothelin-1 & $\begin{array}{l}\text { No, but improved } \\
\text { behavioral and sensory } \\
\text { outcomes }\end{array}$ & Duricki et al., 2016 \\
\hline HSP-27 & $\begin{array}{l}\text { HSV } \\
\text { HSV }\end{array}$ & $\begin{array}{l}3 \text { days pre- } \\
30 \text { mins post- }\end{array}$ & $\begin{array}{l}\text { Rat; } 30 \text { min MCAO } \\
\text { Rat; } 30 \text { min MCAO }\end{array}$ & $\begin{array}{l}\text { Yes } \\
\text { Yes }\end{array}$ & $\begin{array}{l}\text { Badin et al., } 2006 \\
\text { Badin et al., } 2009\end{array}$ \\
\hline HSP-70 & $\begin{array}{l}\text { HSV } \\
\text { HSV }\end{array}$ & $\begin{array}{l}3 \text { days pre- } \\
30 \text { mins post- }\end{array}$ & $\begin{array}{l}\text { Rat; } 30 \text { min MCAO } \\
\text { Rat; } 30 \text { min MCAO }\end{array}$ & $\begin{array}{l}\text { No } \\
\text { No }\end{array}$ & $\begin{array}{l}\text { Badin et al., } 2006 \\
\text { Badin et al., } 2009\end{array}$ \\
\hline HSP-72 & $\begin{array}{l}\text { HSV } \\
\text { HSV } \\
\text { HSV } \\
\text { HSV }\end{array}$ & $\begin{array}{l}24 \mathrm{~h} \text { pre- } \\
17 \mathrm{~h} \text { pre- } \\
0.5 \text { and } 2 \mathrm{~h} \text { post- } \\
5 \mathrm{~h} \text { post- }\end{array}$ & $\begin{array}{l}\text { Rat; } 1 \text { h MCAO } \\
\text { Rat; } 8 \text { min bilateral CCA } \\
\text { Rat; } 1 \text { h MCAO } \\
\text { Rat; } 1 \text { h MCAO }\end{array}$ & $\begin{array}{l}\text { Yes } \\
\text { Yes } \\
\text { Yes } \\
\text { No }\end{array}$ & $\begin{array}{l}\text { Yenari et al., } 1998 \\
\text { Kelly et al., } 2002 \\
\text { Hoenn et al., } 2001 \\
\text { Hoenn et al., } 2001\end{array}$ \\
\hline Gpx & HSV & $\begin{array}{l}12 \mathrm{~h} \text { pre- } \\
2 \text { and } 5 \text { h post- }\end{array}$ & $\begin{array}{l}\text { Rat; } 1 \text { h MCAO } \\
\text { Rat; } 1 \text { h MCAO }\end{array}$ & $\begin{array}{l}\text { Yes } \\
\text { Yes }\end{array}$ & $\begin{array}{l}\text { Hoehn et al., } 2003 \\
\text { Hoehn et al., } 2003\end{array}$ \\
\hline CXCL12 (SDF-1 $1 \alpha)$ & $\begin{array}{l}\text { Ad } \\
\text { Ad } \\
\text { rAAV } \\
\text { rAAV }\end{array}$ & $\begin{array}{l}3 \text { days pre- and } \\
7 \text { days post- } \\
7 \text { days post - } \\
7 \text { days post- }\end{array}$ & $\begin{array}{l}\text { Rat; } 1.5 \text { h MCAO } \\
\text { Rat; } 1.5 \text { h MCAO } \\
\text { Mouse; permanent MCAO } \\
\text { Mouse; permanent MCAO }\end{array}$ & $\begin{array}{l}\text { Yes } \\
\text { Yes } \\
\text { Protects myelin sheath } \\
\text { Yes }\end{array}$ & $\begin{array}{l}\text { Yoo et al., } 2012 \\
\text { Yoo et al., } 2012 \\
\text { Li et al., } 2015 \\
\text { Li et al., } 2014\end{array}$ \\
\hline IL-1 receptor antagonist & rAAV & During & $\begin{array}{l}\text { Rat; } 1.5 \mathrm{~h} \text { bilateral CCA and } \\
\text { right } \mathrm{MCAO}\end{array}$ & Yes & Tsai et al., 2003 \\
\hline Netrin-1 & rAAV & 1 day post- & $\begin{array}{l}\text { Rat; } 1 \mathrm{~h} \text { bilateral CCA and left } \\
\text { MCAO }\end{array}$ & $\begin{array}{l}\text { No, but increased } \\
\text { vascularisation and } \\
\text { improved behavior }\end{array}$ & Sun et al., 2011 \\
\hline
\end{tabular}

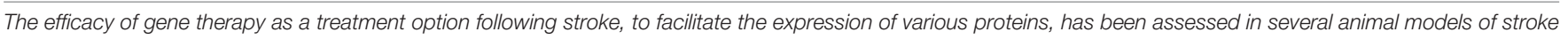

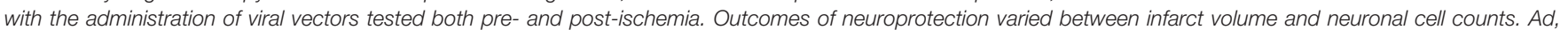

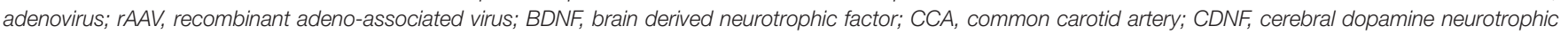

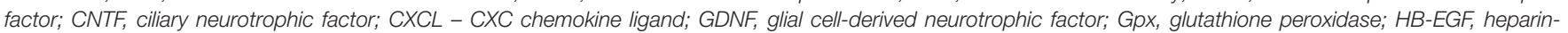

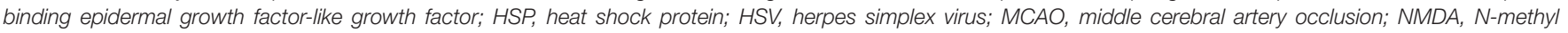
D-aspartate; NT, neurotrophin; SDF, stromal cell-derived factor. 
afforded at the $4 \mathrm{~h}$ post-ischemic administration time-point, which is postulated to be due to decreased protein synthesis following ischemia (Lawrence et al., 1997).

\section{Heat Shock Proteins}

The heat shock proteins (HSP) are stress-related proteins with chaperone properties. Of particular interest are the HSP70 family, comprising of the constitutive HSP-70 and the homologous inducible HSP-72, which are up-regulated following cerebral ischemia (Brea et al., 2015). The over-expression of HSP-72 proteins in transgenic mice has provided evidence of the neuroprotective role following cerebral ischemia (Xu et al., 2011). In addition, the smaller HSP-27 (also known as HSP-25), similarly, provides neuroprotection following ischemia, when over-expressed in a transgenic mouse model (van der Weerd et al., 2010). The success of the HSPs in providing neuroprotection when transduced has been varied (Table 1), with studies finding neuroprotection evident with HSV-HSP72 delivery 3 days pre-insult to $2 \mathrm{~h}$ post-insult, but not when administered $5 \mathrm{~h}$ post-ischemia (Yenari et al., 1998; Hoehn et al., 2001; Kelly et al., 2002). Conversely, HSP-70 did not confer neuroprotection when administered 3 days pre- or $30 \mathrm{~min}$ post-ischemia, while HSP-27 did with similar administration and injury models (Badin et al., 2006, 2009). These differences may, in part, be due to the method in which neuroprotection is measured, with studies varying from counts of transduced surviving striatal neurons to infarct volume analysis following magnetic resonance imaging (Kelly et al., 2002; Badin et al., 2009). Additionally, the neuroprotective effect of HSP-72 may lie not only with its innate role in protein chaperoning, but also in the induction of Bcl-2 expression, possibly enhancing the neuroprotective effect following ischemia (Lawrence et al., 1997).

\section{Antioxidant Enzymes}

Antioxidant enzymes, such as superoxide dismutase (SOD), catalase, and glutathione peroxidase $(\mathrm{Gpx})$, are postulated to reduce brain damage incurred due to increases in reactive oxygen species following stroke. Transgenic animal studies have shown that over-expression, or deficiencies, of antioxidant enzymes affects the outcome following stroke (Murakami et al., 1997; Chan et al., 1998; Kawase et al., 1999). Gene delivery of Gpx both pre- and up to $5 \mathrm{~h}$ post-MCAO conferred neuroprotection, in conjunction with an increase in Bcl-2 (Table 1). It is proposed that the neuroprotective effect seen with administering the gene therapy at $5 \mathrm{~h}$ post-ischemia may be attributed to both the benefit of the antioxidant action, as well as the anti-apoptotic properties of $\mathrm{Bcl}-2$, accounting in part for why the $\mathrm{Bcl}-2$ administration alone was not neuroprotective when administered $4 \mathrm{~h}$ post-ischemia (Hoehn et al., 2001). The HSV construct was reported to drive Gpx expression at $4-6 \mathrm{~h}$ post-administration, which indicates the therapeutic time window for the Gpx action was $9-11 \mathrm{~h}$ post-MCAO, in the rat model. This is in line with the belief that complex pathologies such as stroke will require therapeutic agents to target multiple pathways for inhibition and/or activation to be truly efficacious (Moretti et al., 2015).

\section{Neurotrophins}

Neurotrophins have a role in the regulation of neuronal tissue development and repair, promoting survival, differentiation, and maintenance in physiological and pathological conditions. Neurotrophin gene cassettes, therefore, offer broad potential for therapy following stroke (Lindholm et al., 2007; Machalinski, 2014; Otsuka et al., 2016). Experimentally, various in vitro and in vivo ischemic injury models have been utilized to demonstrate the neuroprotective efficacy of neurotrophins, including brainderived neurotrophic factor (BDNF; Zhang and Pardridge, 2001; Otsuka et al., 2016), glial cell-derived neurotrophic factor (GDNF; Yuan et al., 2013), and nerve growth factor (NGF; Semkova and Krieglstein, 1999; Tabakman et al., 2005). This has been further translated to delivery of gene cassettes for the recombinant neurotrophic factors, including BDNF (Andsberg et al., 2002; Zhang et al., 2011), GDNF (Tsai et al., 2000, 2006; Hermann et al., 2001a,b; Zhang et al., 2002; Harvey et al., 2003; Wong et al., 2005), ciliary neurotrophic factor (CNTF; Hermann et al., 2001a), and cerebral dopamine neurotrophic factor (CDNF; Matlik et al., 2014). These gene therapy agents have been shown to provide neuroprotection with viral vector delivery, including HSV, Ad, and rAAV, in MCAO models of stroke in rodents (Table 1). When the viral vectors were administered either pre-ischemia, during, or up to $1 \mathrm{~h}$ following ischemia, the infarct volume was significantly reduced, as was caspase-3 expression (Hermann et al., 2001a,b; Zhang et al., 2002; Harvey et al., 2003; Matlik et al., 2014). Further increasing the therapeutic window to 6-7 days post-injury, with the administration of heparin-binding epidermal growth factor-like growth factor (HB-EGF; Sugiura et al., 2005), did not provide the same reduction in infarct volume. This outcome may be expected considering the timeline of neuropathological pathways activated in relation to therapy administration time. However, there was an increase in angiogenesis and improved functional recovery, modulated by the gene delivery of HB-EGF. As clinical outcomes in humans are not measured in terms of infarct volumes but rather as an improvement of motor function and cognition, these results in animal models are encouraging for translation of the gene targets, demonstrating a positive outcome coupled with a clinically relevant administration timeframe. Therapeutic targets for the neurotrophin signaling cascade may be very broad, including the neurotrophins themselves, the corresponding tropomyosin-related kinase (Trk) receptors (also referred to as receptor tyrosine kinases), and potentially second messenger-coupled effectors such as ion channels modulated downstream of phospholipase $\mathrm{C} \gamma$ activation.

\section{Chemokines}

Chemokines are inflammatory mediators that are up-regulated following stroke, with a role in recruiting leukocytes to the area of damage in the brain. The resulting inflammation in the brain can increase the severity of the stroke, or conversely the recruited phagocytes aid in cellular debris clearance, or a combination of both (García-Berrocoso et al., 2014). The expression of the chemokine CXCL-12, otherwise known as stromal cellderived factor-1 (SDF-1), is constitutively expressed in the 
brain, with increased expression occurring following ischemia (Wang et al., 2012). Studies modulating endogenous CXCL12 following stroke provide contrasting results. The inhibition of CXCL-12 with the receptor CXCR4, by delivery of receptor antagonist during the acute post-ischemic time period, improved behavioral recovery and reduced infarct volumes (Ruscher et al., 2013). Similarly, rAAV gene delivery of the IL-1 receptor antagonist reduced infarct volume (Table 1) (Tsai et al., 2003). However, in a study with forced limb use following stroke, the administration of the CXCR4 antagonist resulted in a deficit in recovery with worse motor and cognitive outcomes (Zhao et al., 2015). Gene delivery studies have provided evidence of the benefit of CXCL-12 following stroke. Adenoviral or rAAV gene delivery of CXCL-12 into mice and rats, administered from 3 days pre-ischemia to 7 days post-ischemia reduced brain atrophy, maintained myelin sheath integrity, increased oligodendrocyte progenitor cell proliferation and migration, and the promotion of angiogenesis (Yoo et al., 2012; Li et al., 2014, 2015). Further contrast is seen in clinical studies, with a positive correlation between increased serum CXCL-12 levels and poor outcome in stroke patients in a Chinese cohort, but increases in CXCL-12 serum levels in patients transplanted with autologous mesenchymal stem cells correlating to improved outcome (Lee et al., 2010; Liu et al., 2015; Cheng et al., 2016).

\section{Guidance Proteins}

In contrast to therapeutic proteins targeting neuroprotection, gene therapy can also be utilized to express proteins to aid in regeneration. Netrins are axon and cell guidance proteins, that are expressed both during neural development and in the mature nervous system in physiological conditions, with up-regulation of expression occurring in the peri-infarct region 14 days following ischemia (Moore et al., 2007; Tsuchiya et al., 2007). Gene delivery

\section{REFERENCES}

Akli, S., Caillaud, C., Vigne, E., Stratford-Perricaudet, L. D., Poenaru, L., Perricaudet, M., et al. (1993). Transfer of a foreign gene into the brain using adenovirus vectors. Nat. Genet. 3, 224-228. doi: 10.1038/ng0393-224

Andsberg, G., Kokaia, Z., Klein, R. L., Muzyczka, N., Lindvall, O., and Mandel, R. J. (2002). Neuropathological and behavioral consequences of adeno-associated viral vector-mediated continuous intrastriatal neurotrophin delivery in a focal ischemia model in rats. Neurobiol. Dis. 9, 187-204. doi: 10.1006/nbdi.2001.0456

Arvidsson, A., Kirik, D., Lundberg, C., Mandel, R. J., Andsberg, G., Kokaia, Z., et al. (2003). Elevated GDNF levels following viral vector-mediated gene transfer can increase neuronal death after stroke in rats. Neurobiol. Dis. 14, 542-556. doi: 10.1016/j.nbd.2003.08.002

Badin, R. A., Lythgoe, M. F., van der Weerd, L., Thomas, D. L., Gadian, D. G., and Latchman, D. S. (2006). Neuroprotective effects of virally delivered HSPs in experimental stroke. J. Cereb. Blood Flow Metab. 26, 371-381. doi: 10.1038/sj.jcbfm.9600190

Badin, R. A., Modo, M., Cheetham, M., Thomas, D. L., Gadian, D. G., Latchman, D. S., et al. (2009). Protective effect of post-ischaemic viral delivery of heat shock proteins in vivo. J. Cereb. Blood Flow Metab. 29, 254-263. doi: 10.1038/jcbfm.2008.106

Banks, P., Franks, N. P., and Dickinson, R. (2010). Competitive inhibition at the glycine site of the N-methyl-D-aspartate receptor mediates xenon neuroprotection against hypoxia-ischemia. Anesthesiology 112, 614-622. doi: 10.1097/ALN.0b013e3181cea398 of netrin-1 with rAAV, 1 day following ischemia, resulted in an increase in peri-infarct vascularisation and immature neuronal migration. Despite the lack in reduction of infarct volume, there was an improvement in post-stroke locomotor activity, motor asymmetry, and exploratory behavior (Sun et al., 2011).

\section{CONCLUSION}

Stroke is a complex pathology with a multitude of biochemical, cellular, and molecular pathways instigated differentially over time, providing a challenge to target therapeutically, while also providing multiple opportunities for intervention. The aim for stroke researchers to develop therapeutics that will increase survival probability of patients, as well as improve cognitive and behavioral recovery, whilst ensuring therapeutic delivery within a clinically relevant timeframe is challenging. However, enhancing the expression of endogenous proteins or facilitating expression in areas most susceptible to damage, by gene delivery, provides promise, with progress being made in both the therapeutic window for delivery and an expanding range of potential protein targets. The use of these therapies in conjunction with the currently available treatments, such as rtPA or mechanical clot removal, is an additional area of research to be explored. Despite the promising progress, further research will need to be undertaken before these therapies reach clinical trials, as the regulatory challenges for gene therapy trials are particularly arduous.

\section{AUTHOR CONTRIBUTIONS}

The authors listed have made substantial, direct and intellectual contributions to the work, and approved it for publication.

Bloom, D. C., Maidment, N. T., Tan, A., Dissette, V. B., Feldman, L. T., and Stevens, J. G. (1995). Long-term expression of a reporter gene from latent herpes simplex virus in the rat hippocampus. Brain Res. Mol. Brain Res. 31, 48-60. doi: 10.1016/0169-328x(95)00031-m

Brea, D., Agulla, J., Staes, A., Gevaert, K., Campos, F., Sobrino, T., et al. (2015). Study of protein expresion in peri-infarct tissue after cerebral ischemia. Sci. Rep. 5:12030. doi: 10.1038/srep12030

Broderick, J. P., Palesch, Y. Y., Demchuk, A. M., Yeatts, S. D., Khatri, P., Hill, M. D., et al. (2013). Endovascular therapy after intravenous t-PA versus t-PA alone for stroke. N. Engl. J. Med. 368, 893-903. doi: 10.1056/NEJMoa1214300

Carpenter, D. E., and Stevens, J. G. (1996). Long-term expression of a foreign gene from a unique position in the latent herpes simplex virus genome. Hum. Gene Ther. 7, 1447-1454. doi: 10.1089/hum.1996.7.12-1447

Chan, P. H., Kawase, M., Murakami, K., Chen, S. F., Li, Y., Calagui, B., et al. (1998). Overexpression of SOD1 in transgenic rats protects vulnerable neurons against ischemic damage after global cerebral ischemia and reperfusion. J. Neurosci. 18, 8292-8299.

Chen, B., Zhang, F., Li, Q.-Y., Gong, A., and Lan, Q. (2016). Protective effect of AdVEGF-Bone mesenchymal stem cells on cerebral infarction. Turk. Neurosurg. 26, 8-15. doi: 10.5137/1019-5149.jtn.11488-14.3

Cheng, X., Lian, Y., Ma, Y., Xie, N., and Wu, C. (2016). Elevated serum levels of CXC Chemokine Ligand-12 are associated with unfavorable functional outcome and mortality at 6-month follow-up in chinese patients with acute ischemic stroke. Mol. Neurobiol. doi: 10.1007/s12035-015-9645-9 [Epub ahead of print]. 
Czabotar, P. E., Lessene, G., Strasser, A., and Adams, J. M. (2014). Control of apoptosis by the BCL-2 protein family: implications for physiology and therapy. Nat. Rev. Mol. Cell Biol. 15, 49-63. doi: 10.1038/nrm3722

Davidson, B. L., Stein, C. S., Heth, J. A., Martins, I., Kotin, R. M., Derksen, T. A., et al. (2000). Recombinant adeno-associated virus type 2, 4, and 5 vectors: transduction of variant cell types and regions in the mammalian central nervous system. Proc. Natl. Acad. Sci. U.S.A. 97, 3428-3432. doi: $10.1073 /$ pnas.050581197

de Los Rios la Rosa, F., Khoury, J., Kissela, B. M., Flaherty, M. L., Alwell, K., Moomaw, C. J., et al. (2012). Eligibility for intravenous recombinant tissuetype plasminogen activator within a population: the effect of the european cooperative acute stroke study (ECASS) III trial. Stroke 43, 1591-1595. doi: 10.1161/strokeaha.111.645986

Dirnagl, U., Iadecola, C., and Moskowitz, M. A. (1999). Pathobiology of ischaemic stroke: an integrated view. Trends Neurosci. 22, 391-397. doi: 10.1016/S01662236(99)01401-0

Duricki, D. A., Hutson, T. H., Kathe, C., Soleman, S., Gonzalez-Carter, D., Petruska, J. C., et al. (2016). Delayed intramuscular human neurotrophin-3 improves recovery in adult and elderly rats after stroke. Brain 139, 259-275. doi: 10.1093/brain/awv341

Emberson, J., Lees, K. R., Lyden, P., Blackwell, L., Albers, G., Bluhmki, E., et al. (2014). Effect of treatment delay, age, and stroke severity on the effects of intravenous thrombolysis with alteplase for acute ischaemic stroke: a metaanalysis of individual patient data from randomised trials. Lancet 384, 19291935. doi: 10.1016/s0140-6736(14)60584-5

García-Berrocoso, T., Giralt, D., Llombart, V., Bustamante, A., Penalba, A., Flores, A., et al. (2014). Chemokines after human ischemic stroke: from neurovascular unit to blood using protein arrays. Transl. Proteom. 3, 1-9. doi: 10.1016/j.trprot.2014.03.001

Hallek, M., and Wendtner, C. M. (1996). Recombinant adeno-associated virus (rAAV) vectors for somatic gene therapy: recent advances and potential clinical applications. Cytokines Mol. Ther. 2, 69-79.

Harvey, B. K., Chang, C. F., Chiang, Y. H., Bowers, W. J., Morales, M., Hoffer, B. J., et al. (2003). HSV amplicon delivery of glial cell line-derived neurotrophic factor is neuroprotective against ischemic injury. Exp. Neurol. 183, 47-55. doi: 10.1016/S0014-4886(03)00080-3

Hermann, D. M., Kilic, E., Kugler, S., Isenmann, S., and Bahr, M. (2001a). Adenovirus-mediated GDNF and CNTF pretreatment protects against striatal injury following transient middle cerebral artery occlusion in mice. Neurobiol. Dis. 8, 655-666. doi: 10.1006/nbdi.2001.0399

Hermann, D. M., Kilic, E., Kugler, S., Isenmann, S., and Bahr, M. (2001b). Adenovirus-mediated glial cell line-derived neurotrophic factor (GDNF) expression protects against subsequent cortical cold injury in rats. Neurobiol. Dis. 8, 964-973. doi: 10.1006/nbdi.2001.0448

Hoehn, B., Ringer, T. M., Xu, L., Giffard, R. G., Sapolsky, R. M., Steinberg, G. K., et al. (2001). Overexpression of HSP72 after induction of experimental stroke protects neurons from ischemic damage. J. Cereb. Blood Flow Metab. 21, 1303-1309. doi: 10.1097/00004647-200111000-00006

Hoehn, B., Yenari, M. A., Sapolsky, R. M., and Steinberg, G. K. (2003). Glutathione peroxidase overexpression inhibits cytochrome $c$ release and proapoptotic mediators to protect neurons from experimental stroke. Stroke 34, 2489-2494. doi: 10.1161/01.str.0000091268.25816.19

Jeong, H., Yim, H. W., Cho, Y.-S., Kim, Y.-I., Jeong, S.-N., Kim, H.-B., et al. (2014). Efficacy and safety of stem cell therapies for patients with stroke: a systematic review and single arm meta-analysis. Int. J. Stem Cells 7, 63-69. doi: 10.15283/ijsc.2014.7.2.63

Kane, D., Sarafian, T., Anton, R., Hahn, H., Gralla, E., Valentine, J., et al. (1993). Bcl-2 inhibition of neural death: decreased generation of reactive oxygen species. Science 262, 1274-1277. doi: 10.1126/science.82 35659

Kawase, M., Murakami, K., Fujimura, M., Morita-Fujimura, Y., Gasche, Y., Kondo, T., et al. (1999). Exacerbation of delayed cell injury after transient global ischemia in mutant mice with CuZn superoxide dismutase deficiency. Stroke 30, 1962-1968. doi: 10.1161/01.str.30.9.1962

Kelly, S., Zhang, Z., Zhao, H., Xu, L., Giffard, R., Sapolsky, R., et al. (2002). Gene transfer of HSP72 protects cornu ammonis 1 region of the hippocampus neurons from global ischemia: influence of Bcl-2. Ann. Neurol. 52, 160-167. doi: 10.1002/ana.10264
Kilic, E., Hermann, D. M., Kügler, S., Kilic, U., Holzmüller, H., Schmeer, C., et al. (2002). Adenovirus-mediated Bcl-X(L) expression using a neuron-specific synapsin-1 promoter protects against disseminated neuronal injury and brain infarction following focal cerebral ischemia in mice. Neurobiol. Dis. 11, 275284. doi: $10.1006 /$ nbdi.2002.0552

Kitagawa, K., Matsumoto, M., Tsujimoto, Y., Ohtsuki, T., Kuwabara, K., Matsushita, K., et al. (1998). Amelioration of hippocampal neuronal damage after global ischemia by neuronal overexpression of BCL-2 in transgenic mice. Stroke 29, 2616-2621. doi: 10.1161/01.str.29.12.2616

Kleihues, P., and Hossmann, K. (1971). Protein synthesis in the cat brain after prolonged cerebral ischemia. Brain Res. 35, 409-418. doi: 10.1016/00068993(71)90484-7

Lawrence, M. S., McLaughlin, J. R., Sun, G. H., Ho, D. Y., McIntosh, L., Kunis, D. M., et al. (1997). Herpes simplex viral vectors expressing Bcl-2 are neuroprotective when delivered after a stroke. J. Cereb. Blood Flow Metab. 17, 740-744. doi: 10.1097/00004647-199707000-00003

Lee, J., Hong, J., Moon, G., Lee, P., Ahn, Y., and Bang, O. (2010). A longterm follow-up study of intravenous autologous mesenchymal stem cell transplantation in patients with ischemic stroke. Stem cells 28, 1099-1106. doi: $10.1002 /$ stem.430

Lei, Z., Liu, F., Zhang, L., Huang, Y., and Sun, F. (2012). Bcl-2 increases strokeinduced striatal neurogenesis in adult brains by inhibiting BMP-4 function via activation of beta-catenin signaling. Neurochem. Int. 61, 34-42. doi: 10.1016/j.neuint.2012.04.004

Li, Y., Huang, J., He, X., Tang, G., Tang, Y. H., Liu, Y., et al. (2014). Postacute stromal cell-derived factor-1alpha expression promotes neurovascular recovery in ischemic mice. Stroke 45, 1822-1829. doi: 10.1161/strokeaha.114.005078

Li, Y., Tang, G., Liu, Y., He, X., Huang, J., Lin, X., et al. (2015). CXCL12 gene therapy ameliorates ischemia-induced white matter injury in mouse brain. Stem Cells Transl. Med. 4, 1122-1130. doi: 10.5966/sctm.2015-0074

Lindholm, P., Voutilainen, M. H., Lauren, J., Peranen, J., Leppanen, V.-M., Andressoo, J.-O., et al. (2007). Novel neurotrophic factor CDNF protects and rescues midbrain dopamine neurons in vivo. Nature 448, 73-77. doi: 10.1038 /nature05957

Linnik, M. D., Zahos, P., Geschwind, M. D., and Federoff, H. J. (1995). Expression of bcl-2 from a defective herpes simplex virus-1 vector limits neuronal death in focal cerebral ischemia. Stroke 26, 1670-1674: discussion 5. doi: 10.1161/01.str.26.9.1670

Liu, P., Xiang, J.-W., and Jin, S.-X. (2015). Serum CXCL12 levels are associated with stroke severity and lesion volumes in stroke patients. Neurolog. Res. 37, 853-858. doi: 10.1179/1743132815Y.0000000063

Machalinski, B. (2014). Tissue regeneration in stroke: cellular and trophic mechanisms. Expert Rev. Neurotherapeutics 14, 959-969. doi: $10.1586 / 14737175.2014 .939172$

Madsen, T. E., Khoury, J. C., Alwell, K. A., Moomaw, C. J., Kissela, B. M., De Los Rios La Rosa, F., et al. (2015). Analysis of tissue plasminogen activator eligibility by sex in the Greater Cincinnati/Northern Kentucky stroke study. Stroke 46, 717-721. doi: 10.1161/strokeaha.114.006737

Mason, M. R. J., Ehlert, E. M. E., Eggers, R., Pool, C. W., Hermening, S., Huseinovic, A., et al. (2010). Comparison of AAV serotypes for gene delivery to dorsal root ganglion neurons. Mol. Ther. 18, 715-724. doi: 10.1038/mt. 2010.19

Matlik, K., Abo-Ramadan, U., Harvey, B. K., Arumae, U., and Airavaara, M. (2014). AAV-mediated targeting of gene expression to the peri-infarct region in rat cortical stroke model. J. Neurosci. Methods 236, 107-113. doi: 10.1016/j.jneumeth.2014.08.014

Moore, S., Tessier-Lavigne, M., and Kennedy, T. (2007). Netrins and their receptors. Adv. Exp. Med. Biol. 621, 17-31. doi: 10.1007/978-0-387-76715-4_2

Moretti, A., Ferrari, F., and Villa, R. F. (2015). Neuroprotection for ischaemic stroke: current status and challenges. Pharmacol. Ther. 146, 23-34. doi: 10.1016/j.pharmthera.2014.09.003

Moskowitz, M. A., Lo, E. H., and Iadecola, C. (2010). The science of stroke: mechanisms in search of treatments. Neuron 67, 181-198. doi: 10.1016/j.neuron.2010.07.002

Mozaffarian, D., Benjamin, E. J., Go, A. S., Arnett, D. K., Blaha, M. J., Cushman, M., et al. (2015). Heart disease and stroke statistics-2015 update: a report from the american heart association. Circulation 131, e29-e322. doi: 10.1161/cir.0000000000000152 
Murakami, K., Kondo, T., Epstein, C. J., and Chan, P. H. (1997). Overexpression of CuZn-Superoxide dismutase reduces hippocampal injury after global ischemia in transgenic mice. Stroke 28, 1797-1804. doi: 10.1161/01.str.28. 9.1797

Murphy, A., and Fiskum, G. (1999). Bcl-2 and Ca(2+)-mediated mitochondrial dysfunction in neural cell death. Biochem. Soc. Symp. 66, 33-41. doi: $10.1042 / \mathrm{bss} 0660033$

Naldini, L., Blömer, U., Gallay, P., Ory, D., Mulligan, R., Gage, F. H., et al. (1996). In vivo gene delivery and stable transduction of nondividing cells by a lentiviral vector. Science 272, 263-267. doi: 10.1126/science.272.5259.263

Otsuka, S., Sakakima, H., Sumizono, M., Takada, S., Terashi, T., and Yoshida, Y. (2016). The neuroprotective effects of preconditioning exercise on brain damage and neurotrophic factors after focal brain ischemia in rats. Behav. Brain Res. 303, 9-18. doi: 10.1016/j.bbr.2016.01.049

Paciaroni, M., Balucani, C., Agnelli, G., Caso, V., Silvestrelli, G., Grotta, J. C., et al. (2012). Systemic thrombolysis in patients with acute ischemic stroke and internal carotid ARtery occlusion: the ICARO study. Stroke 43, 125-130. doi: 10.1161/strokeaha.111.630624

Paciaroni, M., Inzitari, D., Agnelli, G., Caso, V., Balucani, C., Grotta, J. C., et al. (2015). Intravenous thrombolysis or endovascular therapy for acute ischemic stroke associated with cervical internal carotid artery occlusion: the ICARO-3 study. J. Neurol. 262, 459-468. doi: 10.1007/s00415-0147550-1

Ruscher, K., Kuric, E., Liu, Y., Walter, H. L., Issazadeh-Navikas, S., Englund, E., et al. (2013). Inhibition of CXCL12 signaling attenuates the postischemic immune response and improves functional recovery after stroke. J. Cereb. Blood Flow Metab. 33, 1225-1234. doi: 10.1038/jcbfm.2013.71

Saver, J. L., Goyal, M., Bonafe, A., Diener, H. C., Levy, E. I., Pereira, V. M., et al. (2015). Stent-retriever thrombectomy after intravenous t-PA vs. t-PA alone in stroke. N. Engl. J. Med. 372, 2285-2295. doi: 10.1056/NEJMoa14 15061

Semkova, I., and Krieglstein, J. (1999). Neuroprotection mediated via neurotrophic factors and induction of neurotrophic factors. Brain Res. Rev. 30, 176-188. doi: 10.1016/S0165-0173(99)00013-2

Sugiura, S., Kitagawa, K., Tanaka, S., Todo, K., Omura-Matsuoka, E., Sasaki, T., et al. (2005). Adenovirus-mediated gene transfer of heparin-binding epidermal growth factor-like growth factor enhances neurogenesis and angiogenesis after focal cerebral ischemia in rats. Stroke 36, 859-864. doi: 10.1161/01.str.0000158905.22871.95

Sun, H., Le, T., Chang, T. T. J., Habib, A., Wu, S., Shen, F., et al. (2011). AAVmediated netrin-1 overexpression increases peri-infarct blood vessel density and improves motor function recovery after experimental stroke. Neurobiol. Dis. 44, 73-83. doi: 10.1016/j.nbd.2011.06.006

Sun, Y., Jin, K., Clark, K. R., Peel, A., Mao, X. O., Chang, Q., et al. (2003). Adeno-associated virus-mediated delivery of BCL-w gene improves outcome after transient focal cerebral ischemia. Gene Ther. 10, 115-122. doi: 10.1038/sj.gt. 3301868

Tabakman, R., Jiang, H., Shahar, I., Arien-Zakay, H., Levine, R., and Lazarovici, P. (2005). Neuroprotection by NGF in the PC12 in vitro OGD model: involvement of mitogen-activated protein kinases and gene expression. Ann. N. Y. Acad. Sci. 1053, 84-96. doi: 10.1196/annals. 1344.008

Thrift, A. G., Cadilhac, D. A., Thayabaranathan, T., Howard, G., Howard, V. J., Rothwell, P. M., et al. (2014). Global stroke statistics. Int. J. Stroke 9, 6-18. doi: $10.1111 /$ ijs. 12245

Tsai, T., Chen, S., Xiao, X., Chiang, Y., Lin, S., Kuo, S., et al. (2003). Gene treatment of cerebral stroke by rAAV vector delivering IL-1ra in a rat model. Neuroreport 14, 803-807. doi: 10.1097/01.wnr.0000065732.03340.b5

Tsai, T. H., Chen, S. L., Chiang, Y. H., Lin, S. Z., Ma, H. I., Kuo, S. W., et al. (2000). Recombinant adeno-associated virus vector expressing glial cell linederived neurotrophic factor reduces ischemia-induced damage. Exp. Neurol. 166, 266-275. doi: 10.1006/exnr.2000.7505

Tsai, T. H., Chen, S. L., Xiao, X., Chiang, Y. H., and Tsao, Y. P. (2006). Gene therapy of focal cerebral ischemia using defective recombinant adeno-associated virus vectors. Front. Biosci. 11, 2061-2070. doi: 10.2741/1948

Tsuchiya, A., Hayashi, T., Deguchi, K., Sehara, Y., Yamashita, T., Zhang, H., et al. (2007). Expression of netrin-1 and its receptors DCC and neogenin in rat brain after ischemia. Brain Res. 1159, 1-7. doi: 10.1016/j.brainres.2006. 12.096 van der Weerd, L., Tariq Akbar, M., Aron Badin, R., Valentim, L. M., Thomas, D. L., Wells, D. J., et al. (2010). Overexpression of heat shock protein 27 reduces cortical damage after cerebral ischemia. J. Cereb. Blood Flow Metab. 30, 849-856. doi: 10.1038/jcbfm.2009.249

von Jonquieres, G., Fröhlich, D., Klugmann, C. B., Wen, X., Harasta, A. E., Ramkumar, R., et al. (2016). Recombinant human myelin-associated glycoprotein promoter drives selective AAV-Mediated transgene expression in oligodendrocytes. Front. Mol. Neurosci. 9:13. doi: 10.3389/fnmol.2016. 00013

von Jonquieres, G., Mersmann, N., Klugmann, C. B., Harasta, A. E., Lutz, B., Teahan, O., et al. (2013). Glial promoter selectivity following AAV-delivery to the immature brain. PLoS One 8:e65646. doi: 10.1371/journal.pone.00 65646

Wang, Y., Huang, J., Li, Y., and Yang, G. (2012). Roles of chemokine CXCL12 and its receptors in ischemic stroke. Curr. Drug Targets 13, 166-172. doi: $10.2174 / 138945012799201603$

Watanabe, T., Okuda, Y., Nonoguchi, N., Zhao, M. Z., Kajimoto, Y., Furutama, D., et al. (2004). Postischemic intraventricular administration of FGF-2 expressing adenoviral vectors improves neurologic outcome and reduces infarct volume after transient focal cerebral ischemia in rats. J. Cereb. Blood Flow Metab. 24, 1205-1213. doi: 10.1097/01.wcb.0000136525.75839.41

Wong, L.-F., Ralph, G. S., Walmsley, L. E., Bienemann, A. S., Parham, S., Kingsman, S. M., et al. (2005). Lentiviral-mediated delivery of Bcl-2 or GDNF protects against excitotoxicity in the rat hippocampus. Mol. Ther. 11, 89-95. doi: 10.1016/j.ymthe.2004.08.026

Xu, L., Xiong, X., Ouyang, Y., Barreto, G., and Giffard, R. (2011). Heat shock protein 72 (Hsp72) improves long term recovery after focal cerebral ischemia in mice. Neurosci. Lett. 488, 279-282. doi: 10.1016/j.neulet.2010.11.047

Yenari, M. A., Dumas, T. C., Sapolsky, R. M., and Steinberg, G. K. (2001). Gene therapy for treatment of cerebral ischemia using defective herpes simplex viral vectors. Ann. N. Y. Acad. Sci. 939, 340-357. doi: 10.1111/j.17496632.2001.tb03643.x

Yenari, M. A., Fink, S. L., Sun, G. H., Chang, L. K., Patel, M. K., Kunis, D. M., et al. (1998). Gene therapy with HSP72 is neuroprotective in rat models of stroke and epilepsy. Ann. Neurol. 44, 584-591. doi: 10.1002/ana.410440403

Yoo, J., Seo, J., Eom, J., and Hwang, D. (2012). Effects of stromal cell-derived factor 1alpha delivered at different phases of transient focal ischemia in rats. Neuroscience 209, 171-186. doi: 10.1016/j.neuroscience.2012.02.031

Yuan, M., Wen, S., Yang, C., Pang, Y., Gao, X., Liu, X., et al. (2013). Transplantation of neural stem cells overexpressing glial cell line-derived neurotrophic factor enhances Akt and Erk1/2 signaling and neurogenesis in rats after stroke. Chin. Med. J. 126, 1302-1309.

Zhang, J., Yu, Z., Yu, Z., Yang, Z., Zhao, H., Liu, L., et al. (2011). rAAV-mediated delivery of brain-derived neurotrophic factor promotes neurite outgrowth and protects neurodegeneration in focal ischemic model. Int. J. Clin. Exp. Pathol. 4, 496-504.

Zhang, W. R., Sato, K., Iwai, M., Nagano, I., Manabe, Y., and Abe, K. (2002). Therapeutic time window of adenovirus-mediated GDNF gene transfer after transient middle cerebral artery occlusion in rat. Brain Res. 947, 140-145. doi: 10.1016/S0006-8993(02)02923-2

Zhang, Y., and Pardridge, W. M. (2001). Neuroprotection in transient focal brain ischemia after delayed intravenous administration of brain-derived neurotrophic factor conjugated to a blood-brain barrier drug targeting system. Stroke 32, 1378-1384. doi: 10.1161/01.str.32.6.1378

Zhao, H., Yenari, M., Cheng, D., Barreto-Chang, O., Sapolsky, R., and Steinberg, G. (2004). Bcl-2 transfection via herpes simplex virus blocks apoptosis-inducing factor translocation after focal ischemia in the rat. J. Cereb. Blood Flow Metab. 24, 681-692. doi: 10.1097/01.wcb.0000127161. 89708.a5

Zhao, H., Yenari, M. A., Cheng, D., Sapolsky, R. M., and Steinberg, G. K. (2003). Bcl-2 overexpression protects against neuron loss within the ischemic margin following experimental stroke and inhibits cytochrome $\mathrm{c}$ translocation and caspase-3 activity. J. Neurochem. 85, 1026-1036. doi: 10.1046/j.14714159.2003.01756.x

Zhao, S., Qu, H., Zhao, Y., Xiao, T., Zhao, M., Li, Y., et al. (2015). CXCR4 antagonist AMD3100 reverses the neurogenesis and behavioral recovery promoted by forced limb-use in stroke rats. Restor. Neurol. Neurosci. 33, 809-821. doi: $10.3233 / \mathrm{rnn}-150515$ 
Zhong, L. T., Sarafian, T., Kane, D. J., Charles, A. C., Mah, S. P., Edwards, R. H., et al. (1993). bcl-2 inhibits death of central neural cells induced by multiple agents. Proc. Natl. Acad. Sci. U.S.A. 90, 4533-4537. doi: 10.1073/pnas.90.10.4533

Conflict of Interest Statement: The authors declare that the research was conducted in the absence of any commercial or financial relationships that could be construed as a potential conflict of interest.
Copyright (c) 2016 Craig and Housley. This is an open-access article distributed under the terms of the Creative Commons Attribution License (CC BY). The use, distribution or reproduction in other forums is permitted, provided the original author(s) or licensor are credited and that the original publication in this journal is cited, in accordance with accepted academic practice. No use, distribution or reproduction is permitted which does not comply with these terms. 